\title{
THE REALITY OF EXTERNAL FINANCIAL REPORTING: THE BENEFIT OF THAT REALITY AND ITS COSTS
}

\author{
Milovan Stanišić, Zoran Petrović \\ Faculty of Business in Belgrade, Singidunum University, Belgrade, Serbia
}

\begin{abstract}
:
Users of external financial statements can make the right decisions only if they are based on real financial statements. The reality of the financial statements is directly related to the actual valuation of items in the financial statements, which often requires a valuation of the fair value of certain positions. Assessment may result in direct and indirect costs of the business entity (estimates costs, potential higher costs of property taxes, income increase and profit taxes, etc.). The financial manager is the person who has to decide where the line between reality and the cost of that reality in financial reporting is.
\end{abstract}

\section{Key words:}

financial statements,

evaluation,

reality,

cost of evaluation,

users of financial statements.

\section{INTRODUCTION}

Financial reporting of companies (firms, banks, insurance companies, institutions, etc.) is directed to:

1. internal users - internal financial reporting and

2. external users - external financial reporting (basis of external financial reporting consists of general-purpose financial statements).

In this paper we primarily deal with the reality of external financial reports, cost price of that reality, and the balance between the cost price of that reality and benefits of that reality. Commitment to external financial statements is the consequence of the fact that the reality of external financial reporting is more threatened in comparison with internal financial reporting. Lower vulnerability of reality of internal financial reporting is a consequence of the simple fact that internal financial reports are used primarily by the management of a company, and they are that which directly determine the degree of their reality and which can affect the reality. Therefore, it is logical to expect that the management has a natural need for realistic internal reporting in order to have a realistic, "healthy" basis for their decisionmaking. External financial statements, among other things are used to calculate the tax liability of the company, for making decisions of potential investors and creditors (?). Therefore, there, also exists a "natural" need of the company management to comply with the requirements of the company (that they pay less tax, attract new investors, etc.).

The reality of the financial statements primarily depends on the reality of position evaluation in the financial statements. It is often necessary to make an assessment of fair value of certain positions. Considering the fact that mentioned assessment causes direct and indirect costs it is necessary to make a balance between costs and benefits of lesser or grater reality of financial statements.

In this paper, we are identifying the factors that affect the reality of the financial statements, costs and benefits which are caused by a tendency toward greater reality of the financial statements, as well as who determines the balance between these costs and benefits.

\section{REAL GENERAL PURPOSE FINANCIAL STATEMENTS AND FACTORS AFFECTING THEIR REALITY}

General purpose financial statements are those that are designed to satisfy the needs of users who are not in a position to make requests for shaping financial statements specifically according to their needs. These financial statements meet the common information needs of a wide range of users (IAS 1 Presentation financial statements). In our conditions general financial statements would be those which are submitted to the Agency for Business Registers, except those ones which are prepared in the process of liquidation of a business entitity or similar events. Remark: Considering the fact that in this paper we deal with the reality of general purpose financial statements we will often omit the determinant - general purpose financial statements.

Real general purpose financial statements are those which in fair and objective manner present the financial position of the company on a particular day, the achieved result for the reporting period, the cash flows in that reporting period and the changes in equity. In accounting we cannot talk about absolutely realistic financial reports, but about more or less realistic financial reports (due to the impossibility of achieving absolute reality, the principle of comparability is very important in financial reporting).

Whose interest is that financial statements should have been realistic? - to everybody who, according to them, make their decisions or give consent to the calculations which are based on those financial statements.

The reality of the financial statements is primarily assessed by external auditors (while performing audits of financial statements) and tax authorities (in the case when they are testing ways of calculating tax liabilities of the company - we should know that tax authorities are not primarily interested in the reality of the financial statements, but whether the prescribed accounting and tax regulations are complied with, even if they were such that their application does not reflect the real financial statements). The reality of the financial statements can be evaluated by a bank in processing the loan application when 
submitted by the company. The bank may rely on the report of the external auditor, but it can, also, initiate itself verification of these reports.

From the point of view of these users, benefit from the realities of the financial statements is reflected in avoiding the damage they would have if they made decisions based on financial statements that are not realistic.

The most important factors that influence the reality of general purpose financial statements are:

1. staff requirements,

2. available accounting regulations - a framework for financial reporting,

3. management attitude towards the reality and the activities they undertake and

4. the external requirements of financial reporting.

Staff requirements - Financial statements are drawn up by accountants. The reality of the financial statements depends on:

1. training (expertise) of accountants - accountants must have professional competence for the job they do. Some methods of position evaluation in the financial statements require the expertise of accountants, as well as extensive experience; for example such are the following valuation methods: calculation of depreciation of assets, valuation of assets at fair value, calculation of provisions;

2. His/her awareness of the need and obligation to respect the code of accountants' ethics - Code of Ethics for Professional Accountants requires from an accountant to respect the principle of objectivity. This means that accountants should not digress from the best accounting practice (prescribed inter alia by the framework for financial reporting) in order to present the financial position or financial performance of the company in the way the company's management wants; and

3. The degree of integrity and independence of accountants - accountants need to have a high degree of integrity and resist any possible unjustified demands of the company's management towards unrealistic financial reporting. The degree of its integrity depends not only on the nature of his personality, but also of its economic independence (for example, the ability to find a job in another company).

Framework for financial reporting, among other things, prescribes the procedures for the recognition, evaluation, presentation and disclosure of items in the financial statements. It is, therefore, about accounting matters that primarily affect the reality of financial reporting.

Frameworks for financial reporting are divided into "flexible" and "inflexible" according to the possibility to affect the reality of the financial reporting framework by choosing accounting policies and their method of application (through various forms of assessment). In practice, it is difficult to find a completely "inflexible" frame. In this sense, we can usually talk about "flexible" and less "flexible" framework for financial reporting.

Framework for financial reporting consists of:

1. accounting regulations - comprised of the relevant laws and bylaws;

2. professional accounting regulations - in the Republic of Serbia two types of professional accounting regulation are applied: International Financial Reporting Standards and International Financial Reporting Standard for Small and Medium-sized Entities (IFRS for SMEs); we emphasize that micro and other legal entities do not apply professional accounting regulation, but bylaw issued by the Minister - in fact, it is condensed IFRS for SMEs;

3. The internal general accounting documents - actually they are the adopted accounting policies of the company.
Their choice depends on the possibilities offered within the professional accounting requirements which company must apply, as well as on managerial understanding of financial reporting purpose (as discussed in the context of the representation of a manager as a reality factor in financial reporting).

Framework for financial reporting in the Republic of Serbia is more flexible for some companies compared to some others. In fact, those companies which are allowed to apply International Financial Reporting Standards have a greater choice of accounting policy in relation to companies that are unable to implement these standards. For example, international financial reporting standards for small and medium-sized companies are not allowed to have revaluation of property, plants and equipment. In terms of significant changes in the value of these assets it may lead to their unrealistic reporting in the financial statements.

Managerial attitude towards the reality of financial reporting - the company's managers and accountants have the primary responsibility for the financial statements of the company ("For true and fair presentation of the financial position and successful performance of a legal entity the responsible one is legal representative, the managing authority and supervising body of a legal entity in accordance with law, or an entrepreneur, as well as a responsible person as in Article 14 of this Law “- paragraph 2 of Article 32 of the Accounting Act). Managers choose accounting policies and they are required to implement appropriate measures for applying the selected accounting policies. Management of a company also has primary responsibility for the selection, implementation and control of the implementation of internal controls. Establishing a system of internal audit is also within the scope of the company's management.

The attitude of a manager about the reality of the financial statements essentially depends on his/her position in relation to the owners of capital. For example, if the amount of the salary of a manager depends on the amount of achieved results it is possible that it can be a stimulus to present company tax results greater in amount than those really achieved.

If a company is not doing well and the reality is that a loss will be shown, it can also be a stimulus to company management to use their power and position in the financial reporting process in order to show the result in, for them, the desired amount. Sometimes the interests of capital owners and managers can coincide when it comes to the direction of correcting the results of the company (from the real to the unreal). For example, if reporting a loss means that the company in the coming period will not be able to participate in tenders for contracts then capital owners, also have a stimulus to justify unrealistic financial reporting.

The attitude of management on financial reporting can range from the traditional to the aggressive one and further to the fraudulent financial reporting (Alexandra Fong, "Earnings Management and Corporate Accounting: An Overview", CrossSections, Vol 2, 2006, p.84)

The following graphic shows how the flexibility of the framework can be used, but, also, abused (which means that flexible financial reporting framework represents chance for unrealistic financial reporting) (M. Jones, Creative Accounting, Fraud and International Accounting Standards, University of Bristol)

External financial reporting requirements - the reality of the financial statements is significantly affected by the external conditions of their drawing up. They may be the reason for the unrealistic financial reporting, as well as stimulus for doing so:

1. inflation and changes in exchange rates of foreign currencies regarding the dinar - the existence of inflation and changes in exchange rates of foreign currencies regarding the dinar may lead to unrealistic presentation of assets and liabilities in the financial statements. For example, 
in the Republic of Serbia, real estate and expression of its values, is mainly in foreign currencies (primarily in euros). Change of the dinar value regarding the euro automatically leads to a change in the dinar value of real estate. Considering the fact that in the Republic of Srebia there has been a constant decline of dinar value regarding the euro during the recent years this means that the value of real estate in the ledgers should be adapted to this change;

2. The change in fair value of the assets - if the fair value of the assets which the company owns significantly changes it is necessary to adjust the carrying value of these assets in order to have realistic financial reporting: the assessment of fair value should be done and recorded;

3. The development of financial and commodity markets developed financial and commodity markets provide the pieces of information which are necessary and which facilitate the evaluation of the assets and liabilities of the company;

4. The impact of tax regulations - impact of tax regulation can be classified as stimulus for unrealistic financial reporting. Namely, the high tax rates can, in negative sense, stimulate companies to do unrealistic financial reporting. This is related to the strength and expertise of tax authorities in checking the process of financial reporting company;

5. The development of the external audit - external audit is the defense mechanism of the public, the capital owners, the state and its authorities from fraudulent financial reporting. Its efficiency depends on its development.

\section{COST OF FINANCIAL REPORTING REALITY}

The implementation of specific procedures in financial reporting process causes the formation of the costs. There are two types of costs: primary and secondary ones.

The primary cost of a more realistic financial reporting are primarily a consequence of the cost of the fair value of the assets, liabilities, and implementation of complex accounting and accounting estimates (for example, calculation of provisions).

Secondary costs of realistic financial reporting should be reflected in:

1. Increase in the amount of property taxes - in conditions where there is an increase in property values (due to inflation, decline of the value of the dinar regarding foreign currencies, as well as the real increase in property value) the base for the calculation of property taxes increases; in the Republic of Serbia in 2013 an interesting situation happened: many companies were ready and they did the assessment and increased the carrying value of property, because even so increased property value represented lower base for the calculation of annual taxes on the property than the basis required by the local self-government. In this case the real financial reporting benefited the company as well;

2. increase in the amount of tax liability on the company profits - if, for example, the company has an investment property whose fair value has increased, it would be real to reduce its value to that estimated fair value in the bal- ance. This includes recognition of the formation of revenue which increases taxable income;

3. Other expenses - maintenance of professional competence requires continual monitoring and gaining knowledge of relevant technical, professional and business achievements. This means that it should be invested in the training of company accountants.

\section{BALANCE BETWEEN COSTS AND BENEFITS OF THE FINANCIAL REPORTING REALITY}

The influence of external users on the quality of financial reporting is indirect: the owners of capital influence it over auditors or a new management, the tax authorities by sanctioning non-compliance with prescribed regulations, banks refusing loan applications, and so on. This also means that these users of the financial statements do not decide primarily on the costs of financial reporting and do not decide on the balance between costs and benefits of the external financial reporting reality. Managers of the companies are those who have the final word in determining the balance between costs and benefits of the external financial reporting reality. They observe this balance from their point of view. However, the problem is that the company management relies more on internal financial reports and less on external financial statements for the purposes of managing the company and that the company management can use general purpose financial statements to achieve certain interests (for unjustified tax deductions, obtaining loans, improve business for creditors and shareholders, etc.) It can be expected from the company management to insist on the reality of general purpose financial statements only when that reality coincides with their interests.

\section{CONCLUSIONS}

The reality of the external financial reporting is not easy to achieve. There are several reasons for this. Interest of external users of financial statements do not always coincide with the interests of those involved in the financial reporting process we are primarily referring to managers of companies. Then, a framework for financial reporting may be such that it does not include valuation procedures that provide more realistic value of balance sheet items - for example, the absence of valuation according to fair value of property, plants and equipment in IFRS for SMEs and in Regulation book for micro and other legal entities. Underdeveloped audit profession is a factor of increasing the risk of unrealistic financial reporting. It is realistic to expect that in the future, in addition to the external auditing, accounting services will develop and they will help external us- 
ers to perceive the degree of objectivity of financial statements and how much they can rely on them in making their economic decisions - for example, we expect development in our country services engagements (other than audits) with the expression of beliefs, access to financial statements and others.

\section{REFERENCES}

[1] A. Fong, "Earnings Management in Corporate Accounting: An Overview", Cross-Sections, Vol: 2, 2006, p. 84.

[2] IAS 1 Presentation of financial statements (access: 01.10.2014.), [available on site http://www.ifrs.org/ IFRSs/Pages/IAS.aspxf]

[3] International Ethics Standards Board for Accountants, “2014 Handbook of the Code of Ethics for Professional Accountants" 2014, (access: 01.11.2014.),

[available on site https://www.ifac.org/publicationsresources/2014-handbook-code-ethics-professional-accountants-a]
[4] M. J. Jones, Creative Accounting, Fraud and International Accounting Standards, University of Bristol (access: 01.11.2014.),

[available on site https://www.unisa.edu.au/Global/business/centres/cags/docs/seminars/creative\%20accounting\%20and\%20fraud(aus).pdf]

[5] Narodna skupština Republike Srbije (2014) „Zakon o računovodstvu“, (access: 01.11.2014.), [available on International Auditing and Assurance Standards Board, "HANDBOOK OF INTERNATIONAL QUALITY CONTROL, AUDITING, REVIEW,OTHER ASSURANCE, AND RELATED SERVICES PRONOUNCEMENTS" (2014) (access: 01.11.2014.), [available on site www.ifac. org/publications-resources/2014-handbook-internationalquality-control-auditing-review-other-assurance-a]

[6] Z. Petrović, Finansijsko izveštavanje, Univerzitet Singidunum, Beograd, 2011., [available on site http://www. singipedia.singidunum.ac.rs/content/2193-Finansijskoizve\%C5\%A1tavanje]

\section{REALNOST EKSTERNOG FINANSIJSKOG IZVEŠTAVANJA: KORIST OD REALNOSTI I TROŠAK TE REALNOSTI}

Milovan Stanišić ${ }^{1}$, Zoran Petrović ${ }^{2}$

${ }^{1}$ Poslovni fakultet u Beogradu, Univerzitet Singidunum, Danijelova 32, Beograd, Srbija, mstanisic@singidunum.ac.rs

${ }^{2}$ Poslovni fakultet u Beogradu, Univerzitet Singidunum, Danijelova 32, Beograd, Srbija, zpetrovic@singidunum.ac.rs

\section{Apstrakt:}

Korisnici eksternih finansijskih izveštaja mogu doneti ispravne odluke samo ako su zasnovane na realnim finansijskim izveštajima. Realnost finansijskih izveštaja je neposredno povezana za realnim vrednovanjem pozicija u finansijskim izveštajima, što često zahteva procenu fer vrednosti pojedinih pozicija. Procena može izazvati direktne i indirektne troškove po privredni subjekt (troškovi procene, mogući veći iznos troškova poreza na imovinu, povećanje prihoda i poreza na dobit, itd.). Finansijski rukovodilac je lice koje treba da izvaga gde je granica između realnosti i troškova te realnosti u finansijskom izveštavanju.

\section{Ključne reči:}

finansijski izveštaji, procena, realnost, troškovi procene, korisnici finansijskih izveštaja. 